\title{
A Project Feasibility Study of Establishing a University of Bohol Student Center at Tagbilaran City
}

\author{
HAZEL G. BUNGABONG \\ hgbungabong@universityofbohol.edu.ph \\ https://orcid.org/0000-0001-9006-921X \\ MICHAELA D. ROSALEJOS \\ mdrosalejos@universityofobohol.edu.ph \\ https://orcid.org/0000-0003-0078-8435
}

AVA LOURDES M. BARIMBAO

barmibaoavalourdes@gmail.com https://orcid.org/0000-0003-3266-4453

MAYDEEH FATIMA R. BARIMBAO

maydeethbarimbao@gmail.com https://orcid.org/0000-0001-6851-9157

JOIE CELINE P. CORCIEGA

joiecelinecorciega@gmail.com https://orcid.org/0000-0002-0406-3020

FRITZIE JAY A. OLAIVAR

fritziejayolaivar@gmail.com https://orcid.org/0000-0002-0776-4236

CHERRY MAE L. SUMAYA cherrymae19@gmail.com https://orcid.org/0000-0003-0514-1622 


\begin{abstract}
This feasibility study aims to establish a University of Bohol Student Center at Tagbilaran City. The main proponent of this research is the University of Bohol, and the participants are the college students of the University of Bohol. The establishment of the student center will be situated particularly in Tabaco Street Tagbilaran City. The goal of the study is to determine the viability of establishing a UB Student Center of the different aspects, namely; management, marketing, technical, financial, and socio-economic, respectively. This study used researcher-made questionnaires to gather data from the respondents. The researchers used questionnaires with randomly selected respondents with a total of 360 students from different colleges in the University of Bohol. Based on the conducted research, the researchers found out that UB Student Center is feasible in all aspects covered by this study. The majority of the target respondents are willing to patronize the student center with appropriate facilities and equipment to be offered to their students. With proper management and competent personnel in imposing policies, guidelines, the student center will be efficient and effective in the conduct of business operations. The student center shows profitability is feasible, and the investment is expected to be recouped within twelve years and three months. This feasibility study will contribute a social and economic advantage to the community. The researchers recommend that marketing programs and efforts shall be administered to announce the establishment of the student center publicly.
\end{abstract}

\title{
INTRODUCTION
}

The transition from high school to college is an essential development for studentss potentials in personal and behavioral change. Engaging or being with fellow students sharing the same goals in life, socializing with them can increase the sense of maturity to individuals, especially young people. A sense of achievement, with a sense of freedom and thrill, will overwhelm these goal seekers for this experience will somehow mean survival for them. It is in the adolescence stage, where the relationship between satisfaction in life, social interest, and participation in extracurricular activities was assessed. Adolescents participating in more structured extracurricular activities are said to have higher school 
satisfaction (Gilman, 2001).

In a residential community, students are exposed to the physical, interpersonal, and social environment. This interaction can influence the students in their day-to-day life. Also, adequate physical facilities will make learning conducive. Examples are proper lighting, soundproofing, and furnishing that can make a student room more adequate and private study facility (Riker, \& DeCoster, 2008). Such studies intend to integrate the academic with that of social and holistic approaches that gain favor with academicians in recent years. Some studies have reported few findings of positive and even negative effects of social integration for students on academic aspects at their colleges (Maxwell, 2000).

Research about participation in activities should continue to take into account not only the kind activities that children engage, but a need to take into consideration with whom they interact those activities (Solish, Perry, \& Minnes, 2010). College students are expected to perform and achieve classroom and social world in college life. Their demands include completing course work, developing a social network, and adjusting to independent living. However, if the students failed to manage the stage changes successfully, their emotional health and psychological well-being may degenerate, which can lead to frustration, being-overwhelmed, and low esteem. To cope up with the constant demand in college life, they may participate in recreational activities which have an important role in helping students on improving their quality of life (Collins, Valerius, King, \& Graham, 2001).

A student center is owned or controlled by the institution. Further, it is located on a property that is owned or controlled by the institution and is within the reasonably contiguous geographic area that makes up the campus (Department of Education, 2016).

Adapting this kind of study will surely be of great help to students and to the University itself. Like in other countries, institutions of higher learning are investing heavily in new facilities, student unions, dining facilities and the like that address the non-academic side of campus life. Merely, they do not serve only one purpose. More often than not, they offer a variety of physical spaces where students can eat, socialize, network, study, and relax (Caulfield, 2018). To attract and retain students, universities have increasing demand to provide housing options that can meet the expectations of the millennial generation (La Roche, Flanigan, \& Copeland Jr., 2010). 
Managing time has a more significant effect than stress in leisure activities. Gender differences exist in all measures. Males had less time management behavior than females, but females also have higher academic stress and anxiety, and males have more benefits in leisure activities. To reduce the academic stress of students, reduction of anxiety, and time management in leisure activities may be an effective strategy (Misra, \& McKean, 2000). Even if there are many benefits of an active lifestyle, the lack of physical activity is still the health problem of the college population (Kilpatrick, Herbert, \& Bartholomew, 2005).

Seven principles based on college research help improve undergraduate education. First, it encourages contacts between students and faculty. Second, it develops reciprocity and cooperation among students. Third, it uses active learning techniques. Fourth, it gives prompt feedback. Fifth, emphasizes time on task. Sixth communicates high expectations. And lastly, respects diverse talents and ways of learning (Chickering, \& Gamson, 1987).

Based on the "Production Model for Construction," a theoretical framework of Antunes and Gonzalez (2015), the building construction industry faces challenges, such as increasing project complexity and scope requirements, but shorter deadlines. Additionally, economic uncertainty and rising business competition with a subsequent decrease in profit margins for the industry demands the development of new approaches to construction management. However, the building construction sector relies on practices based on intuition and experience, overlooking the dynamics of its production system. Furthermore, researchers maintain that the construction industry has no history of the application of mathematical approaches to model and manage production. Much work has been carried out on how manufacturing practices apply to construction projects. Nevertheless, there has been little research to understand the fundamental mechanisms of production in construction. This study develops an in-depth literature review to examine the existing knowledge about production models and their characteristics to establish a foundation for dynamic production systems management in construction.

The understanding of what is construction extrapolates its technical characteristics. In this research, construction is not restricted to civil engineering and architecture, but comprehends a broader understanding of building, putting up, setting up, establishing, and assembling. Construction is the materialization of a concept through design, taking into 
account functional requirements and technical specifications for a project product utilizing specialized labor. In other words, it is the creation of a product that will fulfill a strategic goal.

This student housing or dormitories around the country served as a basis or reference in conducting the study - catering services for the students of some universities and institutions. Ateneo de Davao University's Office of the Student Affairs (OSA) follows the specifications in compliance with the Commission on Higher Education Memorandum Order (CMO) 9 series of 2013. It continuously improves the conduct and delivery of student services on its off-campus living student centers.

Entitled Enhanced Policies and Guidelines on Student Affairs and Services, the order calls for, as stated in Article 9 Section 29 on Student Housing and Residential Services, the assistance that should be offered by education providers in ensuring student access to safe accommodation that promotes an appropriate learning environment. CMO 9 further orders schools in providing for either mechanism, or some form of assistance, such as providing a list of student dormitories and housing facilities that are considered to be «safe, clean, affordable, accessible to students with disabilities, and conducive to learning.»

In the University of the Philippines Diliman, they have student accommodation services to bring an efficient learning home for every student in their school. As mentioned in their page, the residence halls that they have conditions the student to have a sound intellectual, emotional, physical, social, cultural, and spiritual goals. They are the home laboratories on the campus where students can have an efficient balance between non-academic and academic learning. No other system of the University has the potential to impact the passing student more than his/ her place of residence. The residence halls' built-in program of activities and services complement the academic programs of the University. It also captures the essential elements of a "home away from home" where the student-residents obtain an enriching group living experience. The institutions are driven to serve and achieve their main goal, which is to satisfy the students in housing accommodation.

A dormitory facility is offered for marine scholars of Cristal-e College in Tawala, Panglao Island, Bohol. In courtesy of Japanese mining company, it is for the students to observe solidification of their student life with the best housing accommodation or student center that they will have. In-campus housing efficiently integrates learning and social opportunities for students. 
It promotes a sense of maturity and a broader sense of knowledge on how to focus on essential things, most specifically on school. Academic and non-academic learning gives them a chance to grow within. Interact with other people and share the same goal. It is a valuable tool to help them focus on what they are prioritizing now because it will surely help them to have a brighter future.

Students who live in the student center are inclined to people having similar goals and academic focus. This atmosphere surely has a positive effect on students. There is a need for this study to further be aware of the basic needs of students to have focus and adequate time in studying away from stress. And also, to have recreation and independence as they get along with their fellow students.

The University of Bohol is home to a mix of students coming from other places brought by a common desire of learning and growth in this institution. As the number of children is increasing in todayss generation, the demand for education is imperative. Since education is an important tool in developing and cultivating one's knowledge and skills, the University of Bohol's mission is not only to educate students but also to let them experience what life is all about which requires hard work and discipline.

The researchers have come up to make a study of a Student Center. The concept of the student center is not just a home to our beloved students but a good standard of living measured in terms of a clean and well-maintained facility such as bedrooms, comfort rooms, bathrooms, kitchen, and also the electricity and water utilities. The student center will provide sleeping and residential place for the students with a friendly environment. The student center maintains accommodation standards that would benefit particularly for college-level students. It will be a threestory building and could accommodate 200 students only. The student center would be affordable, safe, and secure, easy access to living and dining cost.

Aside from that, the student center will work with various departments and students organizations to provide a wide array of educational and entertaining activities. To enable students to engage in leisure and recreational activities that would benefit them physically, emotionally, and socially, as well as developing their talents and skills. Such as recollection, tutorials, activities like Acquaintance Party, Birthdays, Halloween, and Christmas Party. This student center will give opportunities to the University of Bohol college students to experience the communal life with 
discipline. It will also enhance the character that they could express with fellow students apart from enjoying the benefits of the educational facility.

The researchers propose to establish the University of Bohol Student Center at Tabaco Street, Tagbilaran City. The location will be the old building of the University Grade School, which is a meter away from the main campus. The student center will be exclusive only for the students of the University of Bohol.

\section{RESEARCH METHODOLOGY}

This study used quantitative and qualitative methods in attaining the desiderated result that is suitable for the research study. The market survey used a quantitative method which determined the demand of the students. It also employed a qualitative method through Key Informant Interview (KII) related to business aspects, such as management, marketing, technical, and financial. Those data gathering procedures helped the researchers meet the intent of the study to determine if establishing a University of Bohol Student Center in Tagbilaran City is feasible.

The respondents of the study were the college students of the University of Bohol and the key informant. The study was conducted in the school campus of the University of Bohol. The researchers surveyed randomly selected 360 respondents from different colleges at the University of Bohol. The sample size was calculated using the Confidence Interval Formula.

The method of collecting data used was the survey questionnaire. Researchers did pilot testing to check the internal validity and consistency of the tool. It used the questionnaire to collect data. The interview was conducted to facilitate the gathering of data and used to determine the essential facts necessary for the business.

After sufficient data has been collected, it was analyzed and interpreted. The raw data were classified, tallied, and tabulated for easy understanding of the numerical data. To be able to analyze and interpret the data gathered from the survey respondents, the simple percentage will be used by the researchers to determine the percentage in comparing the frequency of the responses to the total number of respondents. Additionally, the researchers used financial analysis methods to determine the test of financial profitability. 


\section{RESULTS AND DISCUSSIONS}

The University of Bohol will establish and manage the student center and will be responsible for the supervision of the operations of the business. The project study is feasible in terms of the management and personnel aspects that implement the rules, policies, guidelines, and staff development programs as well as the effective conduct of business operations. Operation personnel will be responsible for the security and safety of the students in the student center.

As to the Marketing Feasibility, the establishment of University of Bohol Student Center will be feasible as to its marketing aspect. The target market includes students of the University of Bohol who have the desire to stay and willing to patronize the place. Based on the projected results from the survey made, $87.50 \%$ of the 360 sample size consisting of all college students for the $2^{\text {nd }}$ semester of school year 2018-2019 the establishment of the UB student center to be located at Tabaco St., Tagbilaran City. With such high demand, the proposed establishment will have a market share of $5 \%$ for the first two years of operation and $20 \%$ for the succeeding three years.

As to the Technical Feasibility, the University of Bohol Student Center primarily will provide convenience, security, and accommodation to the students. It will also be able to meet the other technical requirements like utilities, machines, and equipment, and supplies. The student center also offered various services involving academic performance enhancement and social relationship. The business will strictly follow all the guidelines, rules, and regulations set by the City Government in its waste disposal and environmental care. The project study is technically feasible because many parents and financial supporters want convenient services with appropriate facilities and equipment.

As to Financial Feasibility, the establishment would entail a total project cost amounting to Php 15,000,000, which will be financed by the proponent. This project will include all the costs incurred for the establishment. The financial analysis derived from the proposed financial statements for the next five years as to the rate of return, payback period, and profitability shows that the business is feasible with regard to its financial aspect. The investment of the proponent is expected to be recovered within twelve years and three months. 
As to Socio-Economic Feasibility, the project is feasible in terms of the socio-economic aspect, considering that the business will contribute a social and economic advantage to the community. As soon as the establishment is realized, it will cater to the demand for quality services at reasonable prices. Personnel will be hired aligned to the services and will enjoy the benefits aside from their compensations. Taxes, permits, and licenses will all be complied and paid by the business, thereby helping the government generate additional income which will then be utilized for the advancement of the country as a whole. This establishment of new business is environmentally justified for it is made not only for development but also for environment conservation. This project study will bring about accelerating economic and physical development.

\section{CONCLUSION}

As evidenced by the results, the researchers conclude that the project study is feasible in all aspects covered by this study. Based on the projected results from the market survey conducted, the majority of the college students in the University are interested in patronizing and living in the student center. However, the sudden increase in the demand and supply gap is reflected by the decrease in demand. The increase in demand was obtained by taking into consideration the percentage increase in supply.

\section{RECOMMENDATIONS}

In view of the preceding findings and conclusions, the researcher came up with the following recommendations.

1. The proponent as early as possible shall start operating the business in the year 2019 by following project timetable to meet the demand and serve the target markets, which are the students;

2. Marketing programs shall be administered to announce the establishment of the project publicly;

3. Operation personnel shall be selected based on the qualifications set forth herein. The orientation of company policies shall also be conducted to promote efficiency and effectiveness of business operations;

4. The creation of social media mileage, such as website, Facebook pages, and the like are also encouraged to capture more target markets; 
5. Based from the survey result, most of the students are willing to stay in a Student Center managed by the University of Bohol for a range amount of 1,000-1,500 pesos; and,

6. It is also suggested that the proposed establishment will be operational $24 / 7$.

\section{REFERENCES CITED}

Antunes, R., \& Gonzalez, V. (2015). A production model for construction: A theoretical framework. Buildings, 5(1), 209-228. Retrieved from https://bit.ly/2m8HM4x, (accessed last 18 January 2018).

Ateneo De Davao University. 2014. Off-campus Living. Retrieved from https://bit.ly/2KCcOVf(Accessed last 10 January 2018).

Caulfield, J. 2018. A New Hampshire college offers student housing as hotel rooms during the summer.Retrieved from https://bit.ly/2FmlnVK,(accessed last 10 January, 2018).

Department of Education (ED), 2016. The Handbook for Campus Safety and Security Reporting. Retrieved fromhttps://bit.ly/2zndYEL, (accessed last 10 January, 2018).

Gilman, R. (2001). The relationship between life satisfaction, social interest, and frequency of extracurricular activities among adolescent students. Journal of youth and adolescence, 30(6), 749-767. Retrieved from https://bit.ly/2L1bssx (accessed last 5 December, 2018).

Kilpatrick, M., Hebert, E., \& Bartholomew, J. (2005). College students' motivation for physical activity: differentiating men's and women's motives for sport participation and exercise. Journal of American college health, 54(2), 87-94. Retrieved from https://bit.ly/2KTahuY (Accessed December 5, 2018).

Maxwell, W. E. (2000). Student peer relations at a community college. Community College Journal of Research \& Practice, 24(3), 207-217. Retrieved from https://bit.ly/2Q6beGa, (accessed 3 December, 2018) 
Misra, R., \& McKean, M. (2000). college students'academic stress and its relation to their anxiety, time management, and leisure satisfaction. American Journal of Health Studies, 16(1), 41-51. Retrieved from https://bit.ly/2SrurPI, (accessed last 5 December, 2018)

Solish, A., Perry, A., \&Minnes, P. (2010). Participation of children with and without disabilities in social, recreational and leisure activities. Journal of Applied Research in Intellectual Disabilities, 23(3), 226-236. Retrieved from https://bit.ly/2Ebus73, (accessed December 5, 2018)

Collins, J. R., Valerius, L., King, T. C., \& Graham, A. P. (2001). The relationship between college students' self-esteem and the frequency and importance of their in recreational activities. NIRSA Journal, 25(2), 38-47. Retrieved from https://bit.ly/2KWHoxO, (accessed December $5,2018)$

LaRoche, C.R., Flanigan, M.A., \& Copeland Jr, P.K. (2010). StudentHousing: Trends, Preferences and Needs. Contemporary Issues in Education Research,3(10),45-50. Retrievedfrom https://bit.ly/2UfJpJO, (accessed December 5, 2018)

Chickering,A.W., \&Gamson,Z.F.(1987). Seven principlesforgood practice in undergraduate education. AAHE bulletin, 3, 7. Retrieved from https:// bit.ly/2rjFcaZ, (accessed December 5, 2018)

Riker, H. C., \&DeCoster, D. A. (2008). The Educational Role in College Student Housing. Journal of College \& University Student Housing, 35(2). Retrieved from http://bit.do/eCRAK, (accessed December 10, 2018)

University of the Philippines Diliman, Student Accommodation. Retrieved from https://bit.ly/2r5RVxK, (accessed last 10 January, 2018) 